La Revue

des Droits

de l'Homme

\section{La Revue des droits de l'homme}

Revue du Centre de recherches et d'études sur les droits fondamentaux

Actualités Droits-Libertés | 2019

\title{
Lawyer client relationship and the latest legislative changes on the obligation to report money laundering (Albania)
}

Chronique des droits et libertés dans les Balkans

Brunilda Bara, Evisa Kambellari and Jonad Bara

\section{(2) OpenEdition \\ Journals}

Electronic version

URL: http://journals.openedition.org/revdh/6549

DOI: $10.4000 /$ revdh.6549

ISSN: 2264-119X

Publisher

Centre de recherches et d'études sur les droits fondamentaux

\section{Electronic reference}

Brunilda Bara, Evisa Kambellari and Jonad Bara, « Lawyer client relationship and the latest legislative changes on the obligation to report money laundering (Albania) », La Revue des droits de l'homme [Online], Actualités Droits-Libertés, Online since 05 June 2019, connection on 06 June 2019. URL http://journals.openedition.org/revdh/6549; DOI : 10.4000/revdh.6549

This text was automatically generated on 6 June 2019.

Tous droits réservés 


\section{Lawyer client relationship and the latest legislative changes on the obligation to report money laundering (Albania)}

Chronique des droits et libertés dans les Balkans

Brunilda Bara, Evisa Kambellari and Jonad Bara

1 In 2016 Albania went through a major justice reform which resulted in new constitutional and legislative changes and the establishment of new state institutions, while others ceased to exist. The justice reform started in 2014 with the Justice Reform Strategy ${ }^{1}$ and was concluded in August 2016 through enactment of Justice Reform Collection of Laws². The reform and the new Constitution aimed to re-conceptualize state institutions, in particular the judiciary and the prosecution, as part of country's efforts to stop the corruption in the justice sector, as well as to enhance the position of the prosecution and the judiciary and break their bonds with politics and crime. The new Constitution ${ }^{3}$ and law no. $84 / 2016^{4}$ provided, among other things, the vetting of judges and prosecutors ${ }^{5}$.

2 Continuing the efforts on the reformation of the justice system, in March 2018 the Albanian Parliament enacted the law on the vetting of the Albanian State Police, ${ }^{6}$ and in July 2018 the law on the legal profession ${ }^{7}$, which abrogated the previous law ${ }^{8}$.

3 Law no.55/2018 "On the legal profession in the Republic of Albania" in force today, provides, among other things, the obligation of lawyers to show due diligence and report any suspicious financial activity of their clients, in accordance with legal provisions in force on money laundering?.

4 Lawyer's obligation to disclose such information was first introduced by the working group established to analyze the justice system in Albania ${ }^{10}$. According to their findings, the proposed changes to the previous law no.9109, dated 17.07.2003 "On the legal profession in the Republic of Albania" amended, were based on other countries' rules and regulations on the legal profession, as well as the recommendations and strategic 
documents of the Council of Bars and of Law Societies of the European Union (CCBE $)^{11}$. According to the accompanying report of the draft-law, the development of the institutional infrastructure of Albania required that lawyers present to the National Chamber of Advocacy of Albania, as the supervising authority of legislation concerning lawyers, information related to their client's money laundering activities, in accordance with the legal provisions in force ${ }^{12}$.

5 However, neither the report of the working group, nor the report accompanying the draft-law make any reference to Directives $2001 / 97 / \mathrm{E}^{13}$ or $2005 / 60 / \mathrm{EC}^{14}$ of the European Parliament and of the Council of the European Union, which provide the obligation of lawyers to disclose information on money laundering activities of their clients ${ }^{15}$. Law no.55/2018 fails also to provide any criteria on such disclosure, the authority to report to, the nature of penalties in case of failure to disclose, whether the obligation includes client's activities conducted prior to the establishment of the lawyer-client relationship, or whether the responsibility is personal or falls also on the legal entity (p.ex. law studio), whether the obligation to disclose includes entities that provide legal advice, etc. Furthermore, while the report of the working group refers to the recommendations and strategic documents of the Council of Bars and of Law Societies of the European Union (CCBE), it fails to explain that the standing of $\mathrm{CCBE}$ on the Directives is entirely contrary to the obligation of lawyers to disclose information on client's activities regarding money laundering or terrorism financing ${ }^{16}$.

\section{Confidentiality of communications v. Duty to disclose}

6 There is no doubt that the role of a lawyer in a democratic society is indispensable for the protection of the rule of law and human rights. The legal profession, as an independent profession, is subject to the principles of moral integrity, confidentiality, respect for ethical rules, avoidance of conflicts of interest, avoidance of any activities inconsistent with the independent exercise of their duties and activities, protection of client's interests and the duty of respect towards the courts. The general principles on the legal profession require the necessary legal framework to guarantee the exercise of such profession ${ }^{17}$.

7 A lawyer's primary duty in the administration of justice is the protection of defendant's rights. In order to protect such rights, his relationship with the client must be based on trust and the confidentiality of their communications. The trust awarded by the client means that he must act in client's best interest ${ }^{18}$. In Albania, the confidentiality of lawyerclient communications is provided by the Constitution of Albania ${ }^{19}$, Article 8 of the European Convention of Human Rights ${ }^{20}$, law no.55/2018 ${ }^{21}$, as well as Albanian Code of Ethics for Lawyers ${ }^{22}$. The Albanian Code of Criminal Procedure (ACCP) provides the obligation of the authorities to guarantee the confidentiality of lawyer-client communications ${ }^{23}$, while specific legal provisions of $\mathrm{ACCP}^{24}$ and Prisons' General Regulation provides cases when communication between the lawyer and his client can be intercepted or mail communications can be opened ${ }^{25}$.

While preserving the independence of the legal profession, protecting legal professional secrecy and the confidentiality of exchanges between lawyers and their clients is of paramount importance, the new legal provisions on the obligation of the lawyer to report and disclose information on client's possible involvement in money laundering or terrorist financing infringe upon such principles, which lie at the very heart of the rights of the defense. When undertaking a case, the lawyer enters into a special professional relationship, under a mandate providing for the provision of services by the lawyer, such 
as building the best possible defense for his client. The new legal provisions undermine the heart of that relationship, the trust the client puts on his lawyer, putting a heavy burden on the lawyer who either must acts in accordance with the legal provision, knowingly violating the principle of the confidentiality of exchanges between lawyer and client and of legal professional privilege; or refuse to comply and expose himself to disciplinary or criminal sanctions, or even the possibility of being struck off from exercising the legal profession at all. As such, the lawyer turns into a whistleblower putting the interests of the authorities over his client's.

The Constitution of Albania and Article 8 of ECHR protect the confidentiality of all communications and correspondence between individuals, affording strengthened protection to exchanges between lawyers and their clients. This is justified by the fact that lawyers are assigned a fundamental role in a democratic society, that of defending litigants. Yet lawyers cannot carry out this essential task if they are unable to guarantee to those they are defending that their exchanges will remain confidential. It is the relationship of trust between them, essential to the accomplishment of that mission, that is at stake ${ }^{26}$.

Indirectly, but necessarily dependent thereupon is the right of everyone to a fair trial, including the right of accused persons not to incriminate them. People believe that lawyers are bound by a duty of confidentiality. As a result, lawyers' obligation to report suspicions of wrongdoings about their clients requires them to make their clients incriminate themselves. In this case client's right to remain silent is also at stake. Should the lawyer inform the client beforehand on his legal obligation to report money laundering activities, or will he be held legally responsible if he does?

11 While corruption, money laundering, criminal organizations, continue to be a major problem for Albania, which could justify the need for legislative changes in this regard, the legal provision on the obligation of the lawyer to disclose such information is very vague, general and can be abusively used by state authorities. Contrary to Directives 2001/97/E and 2005/60/EC, the legal provision does not provide the cases when a lawyer is required to report or the authority he should report to. The responsible authority for the conduct of the lawyers in Albania is the National Chamber of Advocacy of Albania. As such, as a rule, even though the legal provision does not provide so, the lawyer should first inform to the Chamber ${ }^{27}$, as the authority that should evaluate the information provided by the lawyer and decide whether or not forward it to the national authorities. After taking into consideration whether or not there is a suspicion of money-laundering or it appears that the information reported was received in the course of lawyer's activities excluded from the scope of the obligation to report suspicions, the Chamber can decide, as the authority for the protection of lawyer's interests, to forward or not such information to the authorities.

12 Furthermore, the notion of "suspicions" used in the legal provision is very broad, can be interpreted in different ways and is opened to the possibility of being abusively used by national authorities. The legal provision does not provide the nature of the responsibility of the lawyer in case of non-disclosure: whether disciplinary or criminal; or the moment such obligation arises: when the lawyer becomes aware of such activities conducted by his client? What if the activities were conducted before the establishment of lawyer-client relationship? What if lawyer's assistance is requested in connection with the defense or representation of the client in judicial proceedings ${ }^{28}$ ? 
13 According to the Directives lawyer are not subjected to such obligation where the activity in question "relates to judicial proceedings, whether the information they have was received or obtained before, during or after said proceedings, including any advice given with regard to the manner of initiating or avoiding such proceedings, nor where they give legal advice, unless said information was provided for the purpose of moneylaundering or terrorist financing or with the knowledge that the client requested it for the purpose of money-laundering or terrorist financing"29. Meanwhile, the Albanian legal provision in question fails to provide any guarantees in this regard.

Interference with the exercise of the rights of lawyer and CCA's and ECtHR's caselaw

14 There is no discussion on whether or not the legal provision interferes with the exercise of the rights of a lawyer and many countries have had different approaches on the implementation of the Directives ${ }^{30}$. What is important here is to analyze whether the interference of the Albanian legal provision was justified, its proportionality and whether there are other means available to the national authorities to achieve the expected result.

15 As also held by the CCA and the ECtHR, an interference will violate the fundamental rights, if it is not "in accordance with the law", follows a legitimate aim and is not "necessary in a democratic society" to achieve that aim ${ }^{31}$.

16 The important role of the lawyer has been upheld by CCA's and ECtHR's case-law ${ }^{32}$. According to ECtHR, in establishing the right of "everyone" to respect for his "correspondence", Article 8 of the ECHR protects the confidentiality of "private communications" ${ }^{33}$, whatever the content of the correspondence concerned, and whatever form it may take. This means that what Article 8 protects is the confidentiality of all the exchanges in which individuals may engage for the purposes of communication. So, in requiring lawyers to report to the administrative authorities information concerning another person which came into their possession through exchanges with that person, the obligation for them to report suspicions constitutes an interference with lawyers' right to respect for their correspondence. It also constitutes an interference with their right to respect for their "private life", a notion which includes activities of a professional or business nature ${ }^{34}$.

17 Obviously, the legal provision of law no.55/2018 provides an interference with the rights of the exercise of the profession of the lawyer. In requiring lawyers to report to the administrative authorities information concerning another person which came into their possession through exchanges with that person, the obligation for them to report suspicions constitutes an interference with lawyers' right to respect for their correspondence. It also constitutes an interference with their right to respect for their "private life" ${ }^{35}$. Such interference is also "in accordance with the law" as provided by the Constitution of Albania and the ECHR ${ }^{36}$.

18 When discussing on the legitimate aim of the interference, it cannot be argued that the conditions preceding the legislative changes and the justice reform in Albania were prompted by the high level of corruption in the country, especially the judiciary and the prosecution and their ties with politics and crime, the empowerment of criminal organizations, and country's long fight against crime. As such, it is not arguable that the changes were "necessary in a democratic society" as the interference did correspond to a pressing social need and aimed to prevent activities which constitute a serious threat to democracy. 
However, the problem with the legal provision remains its proportionality. While it provides an interference with the rights of the lawyer, the law itself does not offer enough guarantees for the protection of the professional privilege or mechanisms to control the application of the provision by national authorities. As also held by ECtHR, the Convention does not prevent domestic law from allowing for the possibility of providing limitations to individual's rights and freedoms as long as proper safeguards are provided; more broadly, subject to strict supervision, it is possible to impose certain obligations on lawyers concerning their relations with their clients, in the event, for example, that there was plausible evidence of the lawyer's involvement in a crime and in the context of the fight against money-laundering ${ }^{37}$.

Lawyer-client confidentiality rule under the ABA Professional Responsibility Rules and Standards

20 A lawyer's duty to protect the confidentiality of information obtained from his client is set for in rule 1.6 of ABA's Model Rules of Professional Conduct ${ }^{38}$.

21 Disclosure of information adverse to client's interests is limited to cases where the interest of protecting the confidentiality of client-lawyer communications is overridden by the interest of protecting values of life and physical integrity. Under such a condition, information may be disclosed only when it is reasonably certain that a client's actions may result in someone's death or substantial bodily harm, or there is a present and substantial threat that a person will suffer such harm ${ }^{39}$.

The other two situations where a lawyer can overcome his duty of confidentiality are related to cases in which the disclosure would be reasonably necessary to prevent commission of a crime or fraud ${ }^{40}$ or to prevent/mitigate substantial injury to the financial interests of property of another provided that the client uses lawyer's services while in furtherance of the crime or fraud.

When a person who has committed a crime or fraud, thereafter employs a lawyer for representation concerning that offense, the lawyer is not authorized to disclose that information under his duty of confidentiality ${ }^{41}$. Moreover, the duty to report a crime committed by the client in order to prevent, mitigate or rectify substantial injury to the financial interests of property of another that resulted from the commission of that crime, does not apply if the client was not using lawyer's services at the time the crime was committed. In practice, the lawyer's obligation to disclose depends significantly on the fact whether the client is involved in a continued ${ }^{42}$ criminal activity. In that case the lawyer may not assist his client with legal advice and is also ethically justified to withdraw from representation of his client.

The crime-fraud exceptions aim at making legal sanctions against client wrongdoing more effective, and deter lawyers from engaging in a collusive strategy ${ }^{43}$.

Specific ethical rules of professional conduct govern the situation where the client is an organization. A lawyer for the organization has a fiduciary relationship to the organization as client, but not to its constituents or shareholders. Under the ABA Model Rules of Professional Conduct, a lawyer for an organization may represent its members, shareholders or other constituents as long as there is no conflict of interests between the organization on the one side, and the shareholders on the other side ${ }^{44}$.

26 An important question that needs to be addressed when a lawyer is representing an organizational client is to whom does a lawyer tell when he discovers wrongful conduct by a person acting for the corporation? Generally, the lawyer must disclose the facts to 
the highest authority that can act on behalf of the organization as determined by the applicable law ${ }^{45}$ (usually a board of directors or similar governing body). If the highest authority refuses to act in the face of an obvious violation of law, the lawyer may disregard his duty to protect the confidentiality of information obtained by the client and disclose the information to prevent substantial injury to the entity ${ }^{46}$. Therefore, the only situation in which a lawyer for the organization is authorized to disclose information related to an alleged criminal activity carried out by one of its employees or other persons associated with the organization is when he reasonably believes that the violation is reasonably certain to result in substantial injury to the organization. When faced with such a choice, the lawyer need to make a balance between maintaining confidentiality ${ }^{47}$ and assuring that the alleged violation be prevented or rectified.

If we compare the exceptions to the lawyer-client confidentiality rule set by ABA Model Rules to the respective exception set by the Albanian law on the legal profession it is obvious that the second is very broad since it extends a lawyer's obligation to report suspicions on his client's potential involvement in money laundering related activities not only when that would be necessary to prevent the criminal activity, but in any time that a lawyer's knowledge of such facts would help the enforcement of related antimoney laundering legislation.

Under its actual construction the Albanian legal rule on the exception to the lawyerclient confidentiality obligation extends to situations in which a client's involvement in the related criminal activity happened before he employed the services of a lawyer, and as such, it violates the very core of a lawyer-client relationship ${ }^{48}$.

The new regulation in the Albanian Law on Legal Profession, although necessary to today's condition's in Albania, fails to provide any guidelines on the specific situations under which a lawyer's duty to protect the confidentiality of communications with his client is overridden by the public interest of preventing criminal activities of money laundering or financing of terrorism.

In its actual form of construction, the legal provision is evasive as it requires lawyers to overcome their client's confidentiality in any situation deemed necessary to help the implementation of vigilant measures to enforce anti-money laundering legislation and does not offer enough guarantees for the protection of lawyer-client privilege. In this regard, it awards enforcement agencies wide discretion in accessing confidential information with the possible risk of arbitrary administration of justice by the national authorities. Moreover, the Albanian Lawyer's Ethics Code fails to set any relevant rules governing the situation so as to bridge the existing gap in the legal provision of Law no.55/2018 "On the legal profession in the Republic of Albania".

31 Furthermore, there is no indication neither in the law, nor in the Code of Ethics on how a lawyer working for an organization should act when discovering wrongful conduct committed by a person associated with an entity. Since most of money laundering cases reported in Albania involve use of legitimate businesses to cover up for such criminal activity, the regulation of a lawyer's position working for an organization, in terms of his duty to report an ongoing money laundering activity, is necessary to be properly addressed. 
The lack of clear legal standards and rules of professional conduct governing a lawyer's duty to disclose confidential information of his client alleged involvement in money laundering activities puts lawyers in a very puzzling situation which risks to undermine the lawyer-client fiduciary relationship or even lawyer's future as such.

Les Lettres "Actualités Droits-Libertés» (ADL) du CREDOF (pour s'y abonner) sont accessibles sur le site de la Revue des Droits de l'Homme (RevDH) - Contact

\section{NOTES}

1. $\quad<h t t p: / / w w w . e u r a l i u s . e u / o l d /$ images/pdf/Analysis-of-the-Justice-System-inAlbania.pdf>, accessed 21.05.2019

2. <https://www.euralius.eu/index.php/en/library/albanian-legislation/category/103justice-reform-collection-of-laws>, accessed 21.05.2019

3. The Constitution of the Republic of Albania - Annex

4. Law no.84/2016, dated 30.08.2016 "On the transitional evaluation of judges and prosecutors in the Republic of Albania" also known as the Vetting Law

5. All judges and prosecutors of Albania are obliged to undergo the vetting process which consists in the evaluation of judges and prosecutors' assets (with the purpose of identifying assessees who possess or use more assets than they can legitimately explain, or who have failed to accurately and fully disclose their assets and those of their related persons), background assessment (with the purpose of identifying assessees with inappropriate contacts with persons involved in organized crime), as well as proficiency assessment (with the purpose of identifying judges or prosecutors not qualified to perform their function and those who have deficiencies which can be remedied through further education).

6. Law no. $12 / 2018$, dated 05.03 .2018 "On the transitional and periodic re-evaluation of state police, guard of the Republic of Albania and Service for Internal Affairs and Complaints at the Ministry of Interior".

7. Law no.55, dated 23.07.2018 "On the legal profession in the Republic of Albania" (Law no.55/2018)

8. Law no.9109, dated 17.07.2003 "On the legal profession in the Republic of Albania", amended.

9. Law no.55/2018, Article 8/g; Law no.9917, dated 19.05.2008, "On money laundering and financing of terrorism", amended by law no.10391, dated 03.03.2011 
10. The working group included national and foreign experts, experts of the technical secretariat at the Special Committee, under the assistance of EURALIUS mission in Albania

11. <http://www.parlament.al/Files/ProjektLigje/raport_komisioni_avokatit.pdf>, accessed 22.05.2019. According to the working group, Articles 8, 9, 10 and 11 of the draftlaw provided the right and duties of the lawyer, conflicts of interest, confidentiality, and necessary safeguards recognized also by the Charter of Core Principles of the European Legal Profession, the Code of Conduct for Lawyers in the European Union and The Recommendations of the Committee of Ministers of the European Council, in order to ensure an effective protection of individual's rights, guarantee the exercise of lawyer's profession in accordance with the principles of independence, moral integrity, confidentiality, respect for rules of ethics, elimination of conflict of interests, avoiding any activities inconsistent with the independent exercise of lawyer's duties and respect for the justice system. The provisions of this article took into consideration: a) The need to harmonize the legislation with the amendments of the Criminal Procedure Code; b) The provisions of the Directive of the European Parliament and Council on the obligation of lawyers to inform the client of the possibility of following mediation procedures. c) Comments and suggestions presented by lawyers during consultation on the draft-law.

12. <http://www.parlament.al/Files/ProjektLigje/Relacion_projektligji-per-profesionine-avokatit.pdf>, accessed 22.05.2019

13. Dated 04.12.2001. Directive 2001/97/E amended Council Directive 91/308/EEC on prevention of the use of the financial system for the purpose of money laundering

14. Dated 26.10.2005. Directive 2005/60/EC repealed Directive 91/308/EEC. According to Article 2, paragraph 1/3/b of Directive 2005/60/EC, this Directive applies to independent legal professional in specific cases.

15. Since Albania is not a member of the European Union such Directive does not form part of the national legislation. The European Convention on Laundering, Search, Seizure and Confiscation of the Proceeds from Crime and on the Financing of Terrorism, entered into force in Albania on 01.02.2002 does not include independent professions.

16. <https://www.ccbe.eu/fileadmin/speciality_distribution/public/documents/ ANTI_MONEY_LAUNDERING/AML_Position_papers/

EN_AML_20041104_CCBE_position_on_the_requirements_on_a_lawyer_to_report_suspicions_of_money_laundering_and_on accessed 23.05.2019

17. Decision no.07, dated 12.03.2010 of CCA. Application filed by the National Chamber of Advocacy. According to CCA's reasoning on this decision: "Recommendation No. R (2000) 21 of Committee of Ministers of the Council of Europe "On the freedom of exercise of the profession of lawyer" states, inter alia, that all necessary measures should be taken to respect, protect and promote freedom of exercise of the profession of lawyer without discrimination and without improper interference from authorities; decisions concerning authorization to practice as a lawyer or to accede to this profession must be taken by an independent body; bar associations or other lawyer's associations should draw up professional standards and codes of conduct; bar associations or other lawyer's associations should be self-regulated and independent bodies capable of representing lawyer's interests, promoting their continuing education and training and protecting their professional integrity."; Decision no.16, dated 08.06 .2006 of CCA. 
18. Brunilda Bara, Të drejtat themelore të të akuzuarit. Roli i avokatit në garantimin e tyre, Geer Publishing, 2019, p.89

19. The Constitution of the Republic of Albania, Article 31/ç: "In the course of criminal proceedings everyone has the right to - ç) defend himself or through legal assistance of his own choosing; to free and private communications with the lawyer; as well as free legal assistance if he has not sufficient means to pay for."

20. Article 116/1 of the Constitution of Albania provides: "Normative acts that are effective in the territory of Albania are: a) the Constitution; b) ratified international agreements; c) the laws; ç) normative acts of the Council of Ministers.

21. Article 10: "1. The lawyer shall safeguard the professional secrecy and the confidentiality of information shared by his client or any documents made available to him by his client for defense purposes, except in case of written consent. 2. The lawyer shall request the protection of the confidentiality even by his colleagues and the administrative staff working at the same law office.

22. Article 14

23. ACCP, Article 50/2

24. ACCP, Section IV, Interception of communications, Article 221 - Limits of interception

25. Evisa Kambellari, Mbrojtja e Sigurisë së Komunikimeve në Kontekstin Tradicional dhe në Realitetin e Teknologjisë së Informacionit, Phd thesis, University of Tirana, Faculty of Law, July 2014, p. 87

26. Michaud v. France, Application no.12323/11, pp. 118

27. Law no.55/2018, Article 7/f: "During the exercise of his profession the lawyer shall: f) take the necessary measures to ensure professional liability, in accordance with the rules provided by the statute of the National Chamber of Advocacy of Albania".

28. Position of the Council of the Bars and Law Societies of the European Union (CCBE) on the requirements on a lawyer to report suspicions of money laundering and on the European Commission Proposal for a Third EU Directive On Money Laundering Regulations, Council of the Bars and Law Societies of the European Union Publishing, 2004, p.5: "The Directive applies to lawyers when they participate on behalf of their client in any financial or real estate transaction, or by assisting in the planning or execution of transactions for their client. This is regardless of whether a payment in made in cash and regardless of whether the amount is EUR 15.000 or more. ..."

29. Michaud v. France, Application no. 12323/11, pp. 29

30. Implementation of the EU Money Laundering Directive 2001/97/EC, CCBE Overview of the Implementation of the 2001 Money Laundering Directive, (2004), <https:// www.ccbe.eu/fileadmin/speciality_distribution/public/documents/

ANTI_MONEY_LAUNDERING/AML_Position_papers/

EN_AML_20040331_Overview_of_the_implementation_of_the_2001_money_laundering_Directive.pdf», accessed 21.05.2019

31. The Constitution of Albania, Article 17: "Limitation of the rights and freedoms provided for in this Constitution can only be provided by law, for a public interest or for the protection of the rights of others. A limitation shall be in proportion with the situation that has dictated it. 2. These limitations shall not infringe the essence of the rights and freedoms and in no case may exceed the limitations provided for in the European Convention on Human Rights."; Silver and others v. The United Kingdom, 
Applications no.5947/72; no.6205/73; no.7052/75; no.7061/75; no.7107/75; no.7113/75; no.7136/75; Toma v. Romania, Application no.42716/02; Piechowicz v. Poland, Application no.20071/07

32. Decisions no.222, dated 04.11.2002; no.15, dated 10.11.2004; no.37, dated 24.12.2012; no.54, dated 03.05.2012; no.58, dated 24.12.2012 of CCA; etc.. In Casado Coca v. Spain, Application no. $15450 / 89$, the lawyer played a key role in preserving public confidence in the action of the courts; it was essential, therefore, that people should be able to trust in their lawyers, which meant preserving their independence from the authorities. In Xavier Da Silveira v. Francecase, Application no.43757/05, special procedural guarantees were needed concerning searches or visits to a lawyer's offices. The provisions in issue in the present case provided no such guarantees (the part played by the Chairman of the Bar was limited to an advisory role where he was certain that there was nothing suspicious to report) (pp 21).

33. Frérot v. France, Application no.70204/01, pp. 53

34. Niemietz v. Germany, Application no.13710/88, pp. 29

35. Michaud v. France, Application no.12323/11, pp. 91

36. The Constitution of Albania, Article 17; ECHR, Article 8/2

37. André and Another v. France, Application no.18603/03. In this case, the search of lawyer's office had been carried out in the presence of the Chairman of the Bar, which constituted a "special procedural guarantee".

38. In terms of disclosing information pertinent to a client's alleged involvement in a criminal activity, Rule 1/6 (b) provides that: "A lawyer may reveal information relating to the representation of a client to the extent the lawyer reasonably believes necessary: (1) to prevent reasonably certain death or substantial bodily harm; (2) to prevent the client from committing a crime or fraud that is reasonably certain to result in substantial injury to the financial interests or property of another and in furtherance of which the client has used or is using the lawyer's services; (3) to prevent, mitigate or rectify substantial injury to the financial interests or property of another that is reasonably certain to result or has resulted from the client's commission of a crime or fraud in furtherance of which the client has used the lawyer's services." Model Rules of Professional Conduct, American Bar Association Publishing, 2013

39. Model Rules of Professional Conduct, American Bar Association Publishing, 2013, Rule 1.6, Comment 6. See also: State v. Hansen, 122 Wn.2d 712, P.2d 117 (holding that the attorneyclient privilege was inapplicable and the attorney had a duty to report threats of harm relating to a judge, made by a client while attempting to retain the attorney as counsel).

40. State v. Metcalf, 540 P.2d 459, (Wash. Ct. App. 1975); State v. Richards, 97 Wash. 587, 167 P. 47 (1917) (holding that attorney-client privilege is inapplicable to advice sought in furtherance of crime or fraud). Granada Corp. v. First Court of Appeals, 844 S.W.2d 223, 227 (Tex. 1992) (holding that in order for the crime-fraud exception to apply, the proponent must first establish a prima facie showing that a crime or fraud was ongoing or about to be committed); and Volcanic Gardens MGT v. Paxson, 847 S.W.2d at 347 (holding that whether the proponent has established a prima facie showing is a matter for the court to decide).

41. ABA Model Rules of Professional Conduct, Rule 1.6, Comment 8

42. In Jackson v. BellSouth Telecommunications, 181 F. Supp. 2d 1345 (S.D. Fla. 2001), the Court noted that: "Continuity" is both a closed- and open-ended concept, referring either 
to a closed period of repeated conduct, or to past conduct that by its nature projects into the future with a threat of repetition".

43. George M. Cohen, "When Law and Economics Met Professional Responsibility », 67 Fordham Law Review, Volume 6, Issue 2, (1998), p. 273

44. ABA Model Rule of Professional Conduct, Rule 1.13 (g).

45. Ibid, Rule 1.13 (b)

46. Ibid, Rule 1.13 (c)

47. A determination on whether an attorney-client privilege exists in a corporate setting, includes a showing that: (1) the communication originated in a confidence that would not be disclosed; (2) the communication was made to an attorney acting in his legal capacity for the purpose of securing legal advice or services; (3) the communication remained confidential; and (4) the employee who communicated with the attorney is a member of the "control group. See: Cox v. Yellow Cab Co. (1975), 61 Ill. 2d 416, 337 N.E.2d 15; and Consolidation Coal Co. v. Bucyrus-Erie Co., 432 N.E.2d 250 (1982) (holding that the "control group" test limits the privilege to communications made by corporate decision makers or who those substantially influence corporate decisions).

48. As pointed out in N.Y. State Report 479 (1978), "the interests served by the strict rule of confidentiality are far broader than merely those of the client, but include the interests of the public generally and of effective judicial administration". <https://www.nysba.org/ CustomTemplates/Content.aspx?id=7622>, accessed 23.05.2019. The privilege is intended to encourage "full and frank communication between attorneys and their clients and thereby promote broader public interests in the observance of law and the administration of justice". See: Upjohn Co. v. United States, 449 U. S. 383, 389 (1981); Hunt v. Blackburn, 128 U. S. 464,470 (1888).

\section{ABSTRACTS}

While money laundering continues to remain a big problem for Albania due to its link to corruption, organized crime, potential terrorist threats and the continuing informality of the Albanian economy, the latest legislative changes in this regard to the law on the legal profession in Albania interfere with the individual's constitutional and Convention right to a defense lawyer and the lawyer-client privilege. This article tries to examine the conditions that necessitated such legislative changes, the proportionality of the interference on the lawyer-client relationship and its impact on individual's right to a defense lawyer. The article tries to analyze and weight the importance of the special fiduciary relationship between the lawyer and his client vis à vis state's interest in the fight against money laundering.

This paper tends to address the scope of the lawyer-client privilege and a lawyer's duty of confidentiality of communications with his client; the circumstances under which a lawyer is legally required to report suspicions on his client's involvement in money laundering activities; the position of the lawyer in case he files a money laundering report against his client; whether the lawyer should inform his client on the report; whether the changes on the law on the legal profession affect the lawyer-client relationship in terms of protecting privileged or otherwise 
confidential communications; whether there are any guidelines/rules of professional conduct on the steps a lawyer has to follow in order to fulfill his obligation to report money laundering activities; whether the interference justified and whether the legal provisions in force offer sufficient guaranties for the protection of privileged information or the confidentiality of communications.

INDEX

Keywords: Lawyer, client, confidentiality, money laundering, Albania, comparative analysis.

\section{AUTHORS}

\section{BRUNILDA BARA}

Constitutional Court of Albania, Head of the Judicial and Documentation Department

\section{EVISA KAMBELLARI}

Professor at the University of Tirana, Faculty of Law

\section{JONAD BARA}

General Prosecutor's Office of Albania, Foreign Jurisdictional Matter's Department, Judicial Police Officer 